\title{
Developing Craft Village Tourism in the Context of International Economic: A Case Study of Vine Phuc Province, Vietnam
}

\author{
Nguyen Thi Thu Huong \\ Faculty of Business Administration, Academy of Finance \\ E-mail: nguyenthithuhuong@hvtc.edu.vn
}

Ho Thi Hoa

Faculty of Business Administration, Academy of Finance

E-mail: hothihoa@hvtc.edu.vn

\section{Do Thi Nang}

Faculty of Business Administration, Academy of Finance

E-mail: dothinang@hvtc.edu.vn

\section{Nguyen Thi Phuong Loan}

Faculty of Business Administration, Academy of Finance

E-mail: nguyenthiphuongloan@hvtc.edu.vn

\section{Nguyen Linh Phuong}

Faculty of Business Administration, Academy of Finance

E-mail: linhphuongcva@gmail.com

Tran Thi Hien

Faculty of Business Administration, Academy of Finance

E-mail: hientran.1311@gmail.com 
Received: Nov. 5, 2019 Accepted: Dec. 13, 2019 Online published: Dec. 16, 2019

doi:10.5296/ijhrs.v10i1.16045

URL: https://doi.org/10.5296/ijhrs.v10i1.16045

\begin{abstract}
In the trend of openness and international economic integration, traditional craft villages are gradually regaining their positions in the economic, cultural and social life of each country and nation. These villages are like colorful images contributing to recreate the unique, lively, separate and irreplaceable features of the country and people in each area and region. Currently, developing craft village tourism is the subject of various studies, and is the target of many provinces in Vietnam. This paper focuses on analyzing the current status of craft village tourism in Vinh Phuc - a province located in the North of Vietnam, showing the results, limitations as well as proposing a range of recommendations to develop craft village tourism in Vinh Phuc in the context of world economic integration.
\end{abstract}

Keywords: tourism, craft village, craft village tourism

\title{
1. Introduction
}

Even craft village tourism is a new type of tourism, many researchers and experts has appraised it as a high-quality cultural tourism because traditional craft villages are considered as a meaningful humanistic tourism resource, a "living museum" where stores tangible and intangible cultural heritage treasures. Actually, those treasures are diverse, vivid and specific, which contributes to the value system of a national culture. A craft village is not only a place producing unique and sophisticated handicrafts, but also a cultural environment that preserves the quintessence of art and customs of each Vietnamese community group. With this value system, domestic and foreign tourists are able to not only visit the architecture, buy products, but also feel the perseverance and creativity of people passed down through the generations. Besides, through the process of preservation and development of tourism, traditional craft villages will significantly help to solve the employment problems; stabilize the lives of tens of thousands of workers, and promote social development.

Vinh Phuc is a province situated in the Northern key economic region, the gateway to the capital of Hanoi. It is near Noi Bai International Airport and as the bridge connecting the Northwest provinces with Hanoi and the Red River Delta. Hence, Vinh Phuc plays an important role in the regional and national economic development strategies. After more than 20 years of re-establishment, Vinh Phuc has achieved many important achievements in socio-economic development. Moreover, Vinh Phuc is a place with pool of natural and humanistic tourism resources and famous natural landscapes such as Tam Dao national forest, Ban Long waterfall, Dai Lai lake...; many folk festivals imbued with national identity; various historical and cultural relics with historical imprints and spiritual values ( "General introduction of Vinh Phuc Province," 2019)

One thing that only few people know about Vinh Phuc is that it has a wide range of traditional craft villages with hundred of years of age. Recently, Vinh Phuc has issued many 
policies to encourage the development of craft village tourism in order to turn tourism into a key economic sector in the area that both promoting economic growth and preserving the cultural uniqueness of craft villages. However, at present, the development of craft village tourism in Vinh Phuc is not commensurate with its great potential. There have been many studies on craft villages, craft village development, craft village tourism with different approaches, levels and subjects of research. Additionally, there have been no studies mentioning the development of craft village tourism in Vinh Phuc. Therefore, the research "Developing craft village tourism in the context of international economic integration: A case study of Vinh Phuc Province, Vietnam" is very necessary and urgent in terms of theoretical and practical aspects.

\section{Literature Review}

Today, many new types of tourism have been introduced to meet the growing needs of tourists, in which craft village tourism is one of them that attracts a lot of attention from tourists (Vu Minh Hieu and Ida Rasovska, 2017). There are two types of craft villages including traditional craft villages and non-traditional craft villages. Ministry of Agriculture and Rural Development of Vietnam (2006) defined a craft village as a place where there must have at least $30 \%$ of households participating in crafts production activities, at least two years with static business operations; and legal compliance. Furthermore, a craft village can be defined as a traditional one when it gains three criteria of the existence for at least 50 years, produces goods with regional cultural identities and sustains at least one well-known artisan or the village's name (Ministry of Agriculture and Rural Development of Vietnam, 2006). However, there are two different kinds of craft villages: the traditional and the non-traditional or the "new". The new craft village is established to meet the new market demand and the availability of input materials.

Various studies have emphasized the important role of the development of craft village tourism. Barbieri (2015) argued that village tourism was a strong trend in the world. According to Lane and Kastenholz (2015), the combination of tourism and craft villages brings revenue and employment to rural workers. City inhabitants with the modern life and work often feel stress and pressure. They need to refresh in quiet and peaceful settings and return to traditional values. The strengthening of

linkages between tourism and traditional handicrafts is critically important to poverty alleviation in the rural areas (Mitchell, 2012). It is also seen as a tool for the conservation and regeneration of culture in craft villages (Barbieri, 2013). Moreover, it is theorized as craft village tourism explicitly linked to the economic, social, cultural, natural and human structures of the localities in which it takes place (Gao J and $\mathrm{Wu} \mathrm{B,2017).}$

The question for many studies is what factors affect the development of craft village tourism. There have been many extensive researches on craft village tourism conducted in the world. According to Ahmad (2005), a craft village requires to own good conditions in terms of the economy, social, cultural, physical, natural surroundings, non-urbanization, and possess uniqueness in tradition in order to develop tourism. To exploit the advantages for enhancing craft village tourism, it is impossible not to mention the concerns of the State and authorities 
of the localities where tourism activities take place. Certainly, policies of the State and localities have a great influence on the development of craft village tourism. The government needs to be aware of the values of traditional craft villages in tourism development, and thus enact effective policies to encourage locals to develop craft village tourism (Gao J. and Wu B., 2017).

As for the developed tourism villages, traditional craft products are the most important and the main attraction factors of the village and of course, those are the cultural identities of the village (Vu Minh Hieu and Ida Rasovska, 2017). Craft tourism is considered an effective channel for marketing because tourists will be able to buy products even in their home countries (Suzuki, 2006). Tourists visiting the craft villages can experience on how crafts are produced and used in rituals or in daily life as well as purchasing opportunity (UNWTO, 2008). Marques and Lima (2012) mentioned that tourist satisfaction will have an impact on village tourism.

According to Song et al. (2010), tourism activities are all associated with the generation of costs, including the cost of moving from a permanent place of residence to a tourist destination and vice versa, and the cost of living at a tourist place. Actually, costs have a negative impact on tourism demand for craft village tourism because it is one of the reasons that reduce people's desire to travel (Pham Hong Manh, 2009). This is reasonable because craft village tourism can be considered as a typical type of service. Undoubtedly, when the cost of buying this service increases, the demand will decrease and vice versa.

Williams \& Lawson (2001) suggested that local residents' awareness had an important role in promoting craft village tourism to exist and develop. In fact, promoting the image of the craft village helps visitors know more about the tourism products and from there the village will receive more and more attention from tourists (Chen, Lin and Kuo, 2013). Robert W. Mc Intosh (1995) pointed out the relationship between the education level of the head of household and the tourism rate. Accordingly, the higher the educational level of the head of household, the greater the rate of traveling. Thus, the demand for craft village tourism tends to increase when the general cultural level of the people is high and vice versa.

Especially in the context of international economic integration, craft villages will have more opportunities to promote their products to foreign customers. This activity will certainly improve the efficiency and competitiveness of the products on the domestic and foreign markets. Apparently, craft villages have the opportunity to promote their internal resources and make good use of external forces to improve their products' quality and competitiveness. However, facing the trend of world economic integration, craft village tourism also confront with many challenges such as the fierce competition between tourism companies (both in quantity and quality of tourism services), or the impact of the economic downturn causing the decrease in the number of orders for tourism products, the decline in the number of employments and the amount of labor income, the growth of the price of raw materials affecting the production and the attraction to tourists (Vo Minh Thu, 2012). 


\section{Methodology}

In order to achieve the research objectives in this study, the authors mainly used descriptive statistical methods to analyze the reality, opportunities and challenges in developing trade village tourism in Vinh Phuc. Initially, the authors designed the questionnaire to explore the needs of tourists and residents for craft village tourism in Vinh Phuc. Secondly, based on the questionnaire, the authors conducted direct surveys in 11 craft villages of Vinh Phuc. The direct examination will help the authors to understand the situation and make the quality of the survey information become high quality. In this study, the authors surveyed 175 tourists and residents, and used SPSS 22 software to analyze tourism village needs, the status quo and issues related to developing craft villages in Vinh Phuc.

\section{Actual Situation of Craft Village Tourism in Vinh Phuc}

\subsection{Introduction of Craft Villages in Vinh Phuc}

In 2018, there are 27 craft villages in Vinh Phuc meeting the prescribed criteria, including 19 traditional craft villages and 8 new craft villages operating with the main occupations such as carpentry, rattan and bamboo crafts, metal forging, pottery, snake farming, etc. Of which, there are 5,000 companies processing and preserving agriculture, forestry and fishery; 5,000 handicraft and fine art establishments; 4,000 construction material production facilities; 3,000 firms processing raw materials to serve rural industry production; 1,500 facilities for construction, internal transport and 800 facilities planting and trading ornamental creatures. The total number of laborers working in craft villages is more than 54,000; the average income is from VND 5 million to VND 10 million per person per month. (Bich Phuong, 2019)

\subsection{Conditions to Develop Craft Village Tourism in Vinh Phuc}

\section{- Geographical location, technical conditions for tourism development}

In order to create a breakthrough to make tourism a key economic sector of the province, Vinh Phuc always focuses on prioritizing public investment capital to upgrade and develop tourism infrastructure. In the 2011-2017 period, the total state budget capital invested in the tourism field was VND 2,193 billion, of which infrastructure investment in the tourist area was VND 67.1 billion; investment in key projects to create a highlight for tourism development was VND 2,126 billion. In addition to state budget investment, the province actively spent land for tourism projects to attract investment. From 2011 to 2017, the province had 36 DDI projects investing in tourism with the total committed capital of VND 20,612 billion, of which VND 11,336 billion has been used, accounting for $55 \%$ of the total committed capital. (Duc Hien, 2018)

\section{- Source of tourists}

In the period of 2011-2017, the number of tourists to Vinh Phuc increased sharply. Vinh Phuc welcomed 1,789,940 visitors in 2011. Nevertheless in 2017, the number of visitors reached $4,450,000$, an increase of $248.6 \%$; in which, the number of international visitors increased by $135.7 \%$, and that amount towards domestic visitors increased by $250 \%$. In reality, there have 


\section{Macrothink}

International Journal of Human Resource Studies

ISSN 2162-3058 2020, Vol. 10, No. 1

been various tourist attractions in Vinh Phuc, including: Dam Vac, Tam Dao, Tam Dao National Park, Xa Huong Lake, Tay Thien, Truc Lam Zen Monastery, etc.

Table 1. The number of visitors and the total revenue from visitors in Vinh Phuc between 2011 and 2017

\begin{tabular}{|c|c|c|c|c|c|c|c|c|}
\hline Indicator & Unit & 2011 & 2012 & 2013 & 2014 & 2015 & 2016 & 2017 \\
\hline $\begin{array}{c}1 . \text { The } \\
\text { number of } \\
\text { visitors }\end{array}$ & Person & 1.789 .940 & 1.852 .900 & 1.899 .200 & 2.877 .420 & 3.323 .420 & 3.821 .940 & 4.450 .000 \\
\hline $\begin{array}{c}\text { International } \\
\text { visitors }\end{array}$ & Person & 24.680 & 25.399 & 25.847 & 20.334 & 22.340 & 27.323 & 33.500 \\
\hline $\begin{array}{c}\text { - Domestic } \\
\text { visitors }\end{array}$ & $\begin{array}{c}\text { Person } \\
\text { Dision }\end{array}$ & 1.765 .260 & 1.827 .501 & 1.873 .353 & 2.857 .086 & 3.301 .080 & 3.797 .365 & 4.416 .500 \\
\hline $\begin{array}{c}2 . \text { Total } \\
\text { revenue } \\
\text { from visitors }\end{array}$ & $\begin{array}{c}\text { VND } \\
\text { billio } \\
\mathrm{n}\end{array}$ & 738,9 & 760,9 & 776,1 & 1.014 & 1.170 & 1.287 & 1.420 \\
\hline
\end{tabular}

Source: Statistical Yearbook of Vinh Phuc province, 2011 - 2017

Actually, the number of tourists visiting Vinh Phuc with demand for craft village tourism was not much. However, if being properly invested, some traditional craft villages such as Huong Canh pottery village, Trieu De bamboo and rattan village, Hai Luu stone village, Bich Chu carpentry village, Yen Lac carpentry village, Ly Nhan forgery village, Vinh Son snake village, etc, will be able to attract tourists. The advantage of most craft villages is that they are located on favorable transport axes, including both road and river so it is convenient to develop combined tourism programs. In the current trade villages, there are some artisans, individuals and families who are still passionate about the professions. Proudly, traditional products of the craft villages are still remembered and differentiated.

- Accommodation and eating establishments

Apparently, demand for accommodation and eating establishments for tourists to Vinh Phuc in recent years was not much. The time when international and domestic guests staying in Vinh Phuc was quite short, which averages only about 1.4 - 1.8 days ... In fact, average spending per day per an international tourist was VND 1 million in 2011, and that amount towards a domestic visitor was VND 0.4 million. In 2017, the average spending per day per an international visitor increased to 1.6 million, and that amount towards a domestic visitor was 0.8 million. In fact, the room occupancy rate in 2011 was only 35\%. In 2017, it increased to 45\%. The average room 
occupancy rate in the period of 2011-2017 was 41.86\% (Statistical Yearbook of Vinh Phuc province, 2011-2017)

\section{- Demand for typical tourism products}

Vinh Phuc has a number of famous craft villages with well-known products such as Trieu De bamboo and rattan (Lap Thach District), Huong Canh pottery (Binh Xuyen Town), Tam Dao honey, Vinh Son snake... Although the traditional craft villages have created many kinds of unique crafts, they still have no foothold in the tourist destinations. On the other hand, artisans in craft villages have not researched or invested in production and trading of souvenir products for tourism.

Currently, the souvenir market in Vinh Phuc has not really developed in compatible with the cultural resources. (Le Hoan, 2019)

In fact, each tourist area has stalls to sell souvenir products; however, there are not many souvenir products. Most of them are local agricultural products such as bamboo shoots, honey, bananas, etc., while the rest are monotonous items such as brocade clothes, bracelets hands, toys... brought by other merchants from other places.

\section{- Human resource in tourism areas}

Apparently, tourism is increasingly developing, which requires higher quality of human resource in tourism area. It is reported that the number of employees in tourism area in Vinh Phuc province increased from 1,449 in 2011 to 5,750 labours in 2017. In particular the number of employees who attained university and post graduate degrees increased from 224 in 2011 to 1,515, in 2017 (an increase of 676.3\%). In terms of people achieving college and secondary education in 2011, there were 580 labors and it reached 2,750 people in 2017 (an increase of $474.1 \%$ ). Moreover, the number of labours who attained other training methods was 125 in 2011 and went up to 1,050 employees (an increase of 840\%). As regards of people who were untrained, there were 520 labours in 2011, then the figure decreased to 435 in 2017 (a decrease by 16.3\%) (Statistical Yearbook of Vinh Phuc province, 2011 - 2017)

However, in the context of the increasingly deep and comprehensive international integration, Vinh Phuc Tourism's human resources still has many aspects that have not met the requirements of the industry. It is estimated that by 2020, the tourism industry will need about 8.5 thousand employees, in which 3.5 thousand people among them are direct labours (Nguyen Huong, 2018).

\section{- Organizations managing the development of craft village tourism}

In reality, the local state management agency that is in charge of tourism is the Department of Culture, Sports and Tourism. This is a specialized agency under the management of Provincial People's Committees. It is assigned with some tasks related to advising and assisting the provincial people's committee to execute the state management functions on culture, sports and tourism. Under this Department, there are 13 non-business units including Vinh Phuc Tourism information promotion center. Over the previous years, the Party and the authorities of Vinh Phuc province have set the goal of turning tourism into a key economic sector. This objective is clearly stated in the Master Plan for tourism development of Vinh 


\section{Macrothink}

International Journal of Human Resource Studies

ISSN 2162-3058

2020, Vol. 10, No. 1

Phuc province till 2020 with the vision up to 2030. In the orientation to 2030, Vinh Phuc Tourism develops comprehensively and synchronously the technical infrastructure and transportation infrastructure for tourism development (Vinh Phuc Provincial People's committee, 2011).

\section{- Craft villages and craft village tourism introduction and promotion activities}

In recent years, tourism promotion activities have been implemented quite actively and effectively. It is proved by the fact that Vinh Phuc province has established a Tourism Information and Promotion center to undertake the task of executing many promoting and advertising campaigns to promote tourism in the province. In fact, the center has focused on researching and developing new product strategies, and promoting the advantages of Vinh Phuc tourism in order to create new attractions for tourists with some typical activities. For instance, the province has promoted the image of Vinh Phuc and its people through various means such as providing information on Vinh Phuc's tourism website, and tourism news, participating in tourism fairs, building large billboards, and so on. Table 2 shows that the average expenditure for executing and promoting Vinh Phuc tourism in the period from 2011 to 2017 was VND 0.4 billion per year.

Table 2. Average expenditure for executing and promoting Vinh Phuc tourism in the period from 2011 to 2017

\begin{tabular}{|c|c|c|c|c|c|c|c|c|c|}
\hline Index & $\begin{array}{c}\text { Currency } \\
\text { unit }\end{array}$ & $\mathbf{2 0 1 1}$ & $\mathbf{2 0 1 2}$ & $\mathbf{2 0 1 3}$ & $\mathbf{2 0 1 4}$ & $\mathbf{2 0 1 5}$ & $\mathbf{2 0 1 6}$ & $\mathbf{2 0 1 7}$ & $\begin{array}{c}\text { Average } \\
\text { expenditure } \\
\text { between 2011 } \\
\text { and 2017 }\end{array}$ \\
\hline $\begin{array}{c}\text { Budget } \\
\text { capital for } \\
\text { executing and } \\
\text { promoting }\end{array}$ & $\begin{array}{c}\text { VND } \\
\text { Billion }\end{array}$ & 0.2 & 0.3 & 0.5 & 0.5 & 0.5 & 0.5 & 0.3 & 0.4 \\
\hline
\end{tabular}

Source: Statistical Yearbook of Vinh Phuc province, 2011 - 2017

\subsection{Results of Survey on Craft Village Tourism Status in Vinh Phuc Province}

The research team conducted a survey in 11 craft villages in Vinh Phuc Province in March 2019. The results obtained are as follows:

\section{- Tourists to craft villages}

$100 \%$ of tourists under the survey confirmed that tourism was necessary in the current context when income was on the rise and the quality of life has improved. This was shown by the travel frequency of the tourist, in which the travel frequency from 0-2 times per year accounted for $57.8 \%$; 3-5 times per year accounted for 37.7\%; 6-10 times per year made up $2.8 \%$ and over 10 times per year made up $1.7 \%$. Moreover, the type of entertainment tourism accounted for $98.3 \%$ while that of cultural tourism accounted for $44 \%$ and religious tourism 
made up $14.9 \%$.

However, only $4.6 \%$ of tourists showed their interest in craft village tourism in Vinh Phuc province in the future. Why will the demand for craft village tourism of Vinh Phuc province be so low in the future?

Firstly, craft village tourism has not attracted tourists. When interviewing the locals and people, 65.7 of respondents said they had never travelled to craft villages and only $34.3 \%$ of respondents said they had previously travelled to craft villages. There are several craft villages mentioned, including Bat Trang pottery, Phu Lang pottery (Bac Ninh), Van Phuc silk, Dong Ho painting, Chu Dau pottery (Hai Duong), Dong Ky wood, canonical hat from Chuong village (Thanh Oai), Quat Dong embroidery, Chuong My bamboo and rattan village, Ngu Hanh Son stone village (Da Nang), etc. However, only $2.9 \%$ of respondents visited craft villages in Vinh Phuc, such as Bamboo and rattan village (Yen Lac), Huong Canh pottery (Results of the interview made by the authors).

Secondly, the ratio of travellers who have heard about craft village tourism in Vinh Phuc accounts for only $10.9 \%$ and $89.1 \%$ of respondents have never heard or known about it although among 175 interviewees, $40 \%$ of them have travelled to a number of attractions in Vinh Phuc like Tam Dao, Dai Lai, Tay Thien, FLC Vinh Phuc (Results of the interview made by the authors). The percentage of respondents hearing or knowing about craft village tourism in Vinh Phuc from Internet; TV, newspapers and radio; travel agencies; family; friends and colleagues; and others are $6.3 \% ; 4.6 \% ; 0.6 \% ; 2.9 \% ; 3.4 \%$ and $0.6 \%$ respectively.

Therefore, it is obvious that the demand for craft village tourism in Vinh Phuc province is low due to the limited promotion activities.

Table 3. Survey about the demand for travelling to craft villages in Vinh Phuc province

\begin{tabular}{|c|c|c|c|}
\hline No. & Interview questions & Absolute number & $\begin{array}{c}\text { Relative number } \\
(\%)\end{array}$ \\
\hline \multirow[t]{3}{*}{1} & Is travelling necessary? & & \\
\hline & - Yes. & 175 & $100 \%$ \\
\hline & - No. & 0 & $0 \%$ \\
\hline \multirow[t]{5}{*}{2} & Average travel frequency (time per year) & & \\
\hline & $-0-2$ & 101 & $57,8 \%$ \\
\hline & $-3-5$ & 66 & $37,7 \%$ \\
\hline & $-6-10$ & 5 & $2,8 \%$ \\
\hline & $->10$ & 3 & $1,7 \%$ \\
\hline \multirow[t]{4}{*}{3.} & Types of travelling & & \\
\hline & - Medical tourism & 6 & $3.4 \%$ \\
\hline & - Entertainment tourism & 172 & $98.3 \%$ \\
\hline & - Sports tourism & 16 & $9.1 \%$ \\
\hline
\end{tabular}


- Cultural tourism

- Religious tourism

- Others

4.

Have you ever travelled to craft villages?

- No.

- Yes.

60

5. Have you ever travelled to Vinh Phuc?

$$
\text { - No. }
$$

- Yes.

6. Have you ever heard about craft village tourism in Vinh Phuc?

- Yes.

- No.

7. Where did you hear and know about craft village tourism in Vinh Phuc?

- Internet.

- TV, newspapers, radio.

- Family.

- Travel agents.

- Friends and Colleagues.

- Others.

$\begin{array}{ll}11 & 6.3 \% \\ 8 & 4.6 \% \\ 5 & 2.9 \% \\ 1 & 0.6 \% \\ 6 & 3.4 \% \\ 1 & 0.6 \%\end{array}$

8. Have you ever travelled to craft villages in Vinh Phuc?

$$
\begin{aligned}
& \text { - No. } \\
& \text { - Yes. }
\end{aligned}
$$

9. Do you intend to visit craft villages in Vinh Phuc in the near future?

$$
\begin{aligned}
& \text { - Yes } \\
& \text { - No }
\end{aligned}
$$

Source: Results of the interview made by the authors

- Revenues from craft village tourism

According to the figures in the Table 4, it can be seen that only 3 out of 10 craft villages having tourists visiting and shopping, such as Ly Nhan forging village, Bach Luu snake village, Huong Canh pottery village. Since developing tourism, the revenues in these villages increased by $11 \%, 15 \%$ and $10 \%$, respectively. However, Yen Lang, Moc Ha, Thanh Lang and Bich Chu 


\section{Macrothink Institute ${ }^{\text {TM }}$}

carpentry villages, Hai Luu stone processing, Yen Lac bed sheet, and Viet An waterway transport engineering gained no revenue from tourism. The products of these craft villages are not served for tourists. When being interviewed whether they intend to combine doing crafts and tourism, most of households gave the answer "no". In fact, there are some reasons for this result. Initially, it cannot be denied that tourists' visiting may affect production activities in Yen Lang, Lung Ha, Thanh Lang and Bich Chu carpentry, Hai Luu stone carving, Yen Lac bed sheet, Viet An waterway transportation engineering. Moreover, some respondents themselves felt that the activity might not be effective when being carried out in the reality. The polluted environment is also one of the principle reasons for this rejection.

Table 4. Revenues from craft village tourism in Vinh Phuc province

\begin{tabular}{|c|c|c|c|c|c|c|c|c|c|c|}
\hline Criteria & Forging & Snake & $\begin{array}{c}\text { Yen Lang } \\
\text { Carpentry }\end{array}$ & $\begin{array}{c}\text { Lung Ha } \\
\text { Carpentry }\end{array}$ & $\begin{array}{c}\text { Thanh } \\
\text { Lang } \\
\text { Carpentry }\end{array}$ & $\begin{array}{c}\text { Bich Chu } \\
\text { Carpentry }\end{array}$ & $\begin{array}{c}\text { Huong } \\
\text { Canh } \\
\text { pottery }\end{array}$ & $\begin{array}{c}\text { Stone } \\
\text { processing }\end{array}$ & $\begin{array}{c}\text { Bed } \\
\text { sheet }\end{array}$ & $\begin{array}{c}\text { Waterway } \\
\text { transport } \\
\text { engineering }\end{array}$ \\
\hline $\begin{array}{c}\text { 1) Does } \\
\text { your } \\
\text { family } \\
\text { combine } \\
\text { making } \\
\text { crafts with } \\
\text { tourism? }\end{array}$ & Yes & Yes & No & No & No & No & Yes & No & No & No \\
\hline $\begin{array}{c}\text { 2) In } \\
\text { comparison } \\
\text { with the } \\
\text { time before } \\
\text { combining } \\
\text { with } \\
\text { tourism, } \\
\text { does the } \\
\text { revenue } \\
\text { increase? }\end{array}$ & $11 \%$ & $15 \%$ & 0 & 0 & 0 & 0 & $10 \%$ & 0 & 0 & 0 \\
\hline $\begin{array}{c}3) \text { Are } \\
\text { products } \\
\text { from craft } \\
\text { villages } \\
\text { sold to } \\
\text { tourists? }\end{array}$ & Yes & Yes & 0 & 0 & 0 & 0 & Yes & 0 & 0 & \\
\hline
\end{tabular}

Source: Results of the interview made by the authors

\section{- Influences of developing craft village tourism on the environment}

There is no doubt that the development of craft villages has made an important contribution to economic restructuring, job creation and income increasing for people in rural areas. However, apart from the positive aspects of the craft villages, production activities of these places have caused environmental pollution. 


\section{Macrothink Institute ${ }^{\mathrm{TM}}$}

Through the survey made in 27 craft villages, only $11 \mathrm{craft}$ villages collected and processed solid waste and 9 craft villages had solid waste landfills. Sadly, wastewater and gas in craft villages have not been treated yet and they have been discharged directly into the environment. Furthermore, unsystematic and incomprehensive technical construction facilities have led to stagnant sewage. According to the monitoring results of the Center for Natural Resources and Environmental Protection of Vinh Phuc, surface water of the traditional craft village areas showed the signs of pollution. 9 out of 22 villages have surface water which was polluted with $\mathrm{COD}, \mathrm{BOD}_{5}$ (in which the rate of $\mathrm{BOD}_{5}$ exceeded the permitted standard from 1.02 to 11.7 times; and that of COD exceeded from 1.13 to 6.4 times). In fact, the most polluted area was Dong Mau plastic recycling village (Yen Dong commune, Yen Lac district). In this region, the rate of COD exceeded 2.9 times, and the figures for BOD and $\mathrm{TSS}_{5}$ exceeded 3 times and 3.6 times respectively. The rate of solid waste collection in Vinh Phuc craft villages' area was only about 40-55\% with rudimentary and incomplete waste treatment measures. (Phan Manh Cuong, 2013).

Table 5. Environmental pollution in craft villages of Vinh Phuc province

\begin{tabular}{|c|c|c|c|c|}
\hline No. & Name of the craft villages & $\begin{array}{l}\text { Domestic solid } \\
\text { waste (kg per } \\
\text { day) }\end{array}$ & $\begin{array}{l}\text { Solid } \\
\text { waste } \\
\text { (kg per } \\
\text { day) }\end{array}$ & $\begin{array}{l}\Sigma \text { Unexpected solid } \\
\text { waste (kg per day) }\end{array}$ \\
\hline 1 & $\begin{array}{c}\text { Vinh Son Snake Village (Vinh } \\
\text { Tuong district) }\end{array}$ & 1750 & 9000 & 10750 \\
\hline 2 & $\begin{array}{c}\text { Lung Ha Carpentry village (Yen } \\
\text { Phuong commune, Yen Lac } \\
\text { district) }\end{array}$ & 212.8 & 804 & 1016.8 \\
\hline 3 & $\begin{array}{c}\text { Bamboo and rattan village in } \\
\text { Trieu De commune(Lap Thach } \\
\text { district) }\end{array}$ & 2912 & 4160 & 7072 \\
\hline 4 & $\begin{array}{l}\text { Hop Le pottery village (Thanh } \\
\text { Lang town- Binh Xuyen district) }\end{array}$ & 3525.2 & 15780 & 19305.2 \\
\hline 5 & $\begin{array}{l}\text { Xuan Lang pottery village } \\
\text { (Thanh Lang district) }\end{array}$ & 1762.6 & 10460 & 12222.6 \\
\hline 6 & $\begin{array}{c}\text { Vinh Doai traditional Carpentry } \\
\text { village (Yen Lac town) }\end{array}$ & 786.8 & 17000 & 17786.8 \\
\hline
\end{tabular}

Source: Pham Manh Cuong (2013) 
The soil environment in craft villages of Vinh Phuc province generally has not been polluted by heavy metals. However, in the long run, production activities in craft villages are causing pollution to water and air. Consequently, it might lead to soil pollution in the future.

\subsection{Assessment of Results, Limitations and Causes of Limitations in Craft Village Tourism} Activities in Vinh Phuc Province

\section{- Achievements}

Initially, craft village tourism has contributed to the improvement of the living standards for the locals and to the economic restructuring of craft villages in Vinh Phuc Province. Actually, although tourism activities in Vinh Phuc craft villages have not been developed yet, it still brought in socio-economic benefits such as creating jobs, raising income and enhancing the living standard for people in these villages.

Secondly, craft village tourism has contributed to the promotion of rural urbanization in Vinh Phuc Province. In fact, tourism development in these villages not only requires itself to have developing technical infrastructure but also stimulates the development of technical facilities, as well as the development of service, trade sectors, transport, communication, and so on. Furthermore, it helps to improve the knowledge of rural population, accelerate the process of building a new civilized and modern countryside and gradually connect the gap between urban and rural areas. Craft villages with developed tourism have established trade, service and barter exchange centers. These centers are increasingly expanding and developing, which creates innovation in the countryside. In fact, the accumulated financial source of people in the craft villages is higher. Moreover, the quality infrastructure construction such as roads, houses, etc. is enhanced. As a result, there is a gradual establishment of residential cluster, which is developed with an increasingly urban lifestyle.

Thirdly, craft village tourism has promoted the preservation of the craft villages' values. Indeed, craft village tourism has contributed to the preservation and promotion of unique cultural identities of each locality. It has been seen as a useful method to bring traditional cultures, brands, and craft village products to consumers, as tangible and intangible values are always embedded in each product of craft village tourism.

\section{- Drawbacks}

However, besides the achieved results, the development of craft village tourism in Vinh Phuc has revealed many shortcomings, including:

Firstly, the awareness of the role of craft village tourism in some localities has been limited. Actually, this kind of tourism has not been invested properly. Moreover, there have not any specific solutions to encourage and support the development of craft village tourism's services.

Secondly, craft villages areas in Vinh Phuc have developed slowly; there has been lack of resorts to meet the needs of customers, especially international visitors. Undoubtedly, the village tourism products have not had many added values, which have not helped to attract more tourists. Moreover, there has been lack of the connection between tourism and commerce; there have not any shopping centers and entertainment areas to meet the high demand of 
visitors. Indeed, monotonous tourism products and services have been gradually reducing their attraction and competitiveness towards tourists in comparison with the neighboring provinces and cities.

Thirdly, human resources in tourism villages have been limited in both quantity and quality. There is a shortage of human resources as tour guides in different areas, especially in craft village tourism areas.

Fourthly, tourism infrastructure and technical facilities in craft villages have been invested but still not met the demand of tourists. Some craft villages with tourism development potential still have had some limitations in terms of premises for constructing exhibition centers, introducing products, constructing parking lots, toilets, etc. In reality, tourist accommodation establishments of Vinh Phuc have been really small and fragmented. Moreover, they have offered low quality services. Therefore, due to these drawbacks, tourism and craft village tourism in Vinh Phuc have not developed quickly and sustainably into the world.

Fifthly, the funding for development of craft village areas has been limited. As a result, the making of development policies as well as policies to support investors for craft villages are confronting with many difficulties.

Sixthly, the attraction of tourism village products has not been focused on building and promoting. Hence, it has not met consumers' demand and exploited the maximum solvency of tourists. Moreover, tourism activities in craft villages have been fragmented; as well as tourism expertise and other skills have been still limited.

In addition, craft villages have still faced difficulties related to estate, raising capital to expand production scale, there have been shortage in technology to take care and carry out treatment for snakes when epidemics broke out uncontrollably, etc.

\section{- Reasons for limitations}

Firstly, the effectiveness and efficiency of state management have been not high. In fact, there is a lack of close coordination among provincial relevant departments in directing, orienting and encouraging economic sectors to develop craft village tourism. The provincial mechanism and policies to attract investment have not paid attention to stimulate and support investment in developing craft village tourism. Disappointedly, 50\% of surveyed villages showed that the transportation system did not allow large buses to enter the villages.

Secondly, the mechanisms, policies and legal documents for investment in general, and investment in craft village tourism in particular have not been completed, which have reduced the effectiveness of state management as well as investment activities from various enterprises. In fact, the Government still has no specific regulation on construction of craft village tourism areas as stipulated for economic zones, industrial zones, industrial cluster and high-tech zones. Hence, it has resulted in awareness in attracting investment and developing infrastructure as well as technical facilities for craft village tourism.

Thirdly, the awareness of the development of craft village tourism has not been consistent among different levels, sectors, businesses and craft villages. The organizational structure of 
the tourism areas has not yet met the demand for development and followed modern perspective.

Fourthly, the Provincial personnel responsible for managing the introduction and promotion activities for tourism in general and craft village tourism in particular still have lacked of practical skills such as foreign languages, information technology, organizational expertise, interpersonal skills as well as scientific theoretical foundation. As a result, it has affected the organization of festival in the areas to promote the craft village tourism.

Fifthly, the environment of many craft villages in the province has been polluted, accounting for $90 \%$ of surveyed villages. Therefore, it has been seen as one of the main reasons hindering the attraction of tourists in these villages.

Sixthly, the linkage between many travel agencies and craft villages in the province has not been closed and become a unified block to promote the great potential of the craft village as well as the strengths of craft village tourism.

\section{Suggestions}

Firstly, Vinh Phuc needs to identify the development of craft village tourism as an indispensable direction of the province in order to exploit the advantages of developing tourism and craft village tourism because the development of craft village tourism have played a vital role in creating jobs, increasing incomes for workers, and promoting the villages' products more widely to domestic and international tourists, leading to better opportunities for the village's goods.

Secondly, the province should focus on maximizing the potential of craft village tourism, especially the potential of natural landscapes and human resources to build resorts or tours of tourism in general and craft village tourism in particular with high quality to meet the demand to develop tourism in the period of international economic integration.

Thirdly, it is necessary to develop tourism generally and craft village tourism particularly in a sustainable direction in the context of international economic integration: Development of trade village tourism must be combined with the purpose of preserving and promoting historical values, cultural identity, environmental protection and effective exploitation, preservation of natural resources and humanities resources of these villages.

Fourthly, it is suggested that the province should promote awareness on the role of developing craft village tourism for the locals and workers. Skills on craft villages and craft village tourism for workers should be also improved.

Fifthly, the province should create the link to develop tourism and craft village tourism to diversify tourism products, improve the efficiency of craft village tourism. As a result, it will meet the need of tourists in the context of international economic integration.

Sixthly, developing tourism in craft villages must ensure the rational and economical use of resources, fuels and materials in manufacturing the villages' products as well as in craft village tourism activities; properly exploiting and using natural resources such as soil, water, 
organisms, minerals, etc., in the activities of craft villages and craft village tourism. Actually, there should have a system for collecting and treating waste from production activities craft villages and craft village tourism to preserve healthy, clean and beautiful craft village environments.

\section{Reference}

Ahmad, A. (2005). Tourism Village: A Conceptual Approach. Asia-Europe Seminar on Cultural Heritage, Man and Tourism in Hanoi-Vietnam. May 2001.

Barbieri. (2015). On the demand of agritourism: a cursory review of methodologies and practice. Tourism planning and Development, December.

Bich, P. (2019, June 10). Giũ chân lao động trẻ trong các làng nghề truyền thống [Keeping young employees in traditional craft villages]. Retrieved from https://vinhphuc.gov.vn/ct/cms/tintuc/Lists/VanHoaXaHoi/View_Detail.aspx?ItemID=9316.

Chen, L. C., Lin, S. P., \& Kuo, C. M. (2013). Rural tourism: Marketing strategies for the bed and breakfast industry in Taiwan. International Journal of Hospitality Management, 32(1), 278-286. https://doi.org/10.1016/j.ijhm.2012.07.005

Circular No. 116/2006/TT-BNN dated December 18, 2006, providing guidance on implementation of some articles of the Government's Decree No. 66/2006/ND-CP on development of rural professions (Ministry of Agriculture and Rural development) (Vn.).

Decision No. 1335/QD-UBND dated June 06, 2011 approving mater plan for tourism development in Vinh Phuc province till 2020 with the vision up to 2030 (Vinh Phuc Provincial People's committee) (Vn.)

Duc, H. (2018, October 05). Vĩnh Phúc thúc đẩy phát triển du lịch [Vinh Phuc province promotes tourism]. Retrived from https://vinhphuc.gov.vn/ct/cms/tintuc/Lists/VanHoaXaHoi/View_Detail.aspx?ItemID=8879.

Gao, J., \& Wu, B. (2017). Revitalizing traditional villages through rural tourism: A case study of Yuanjia Village, Shaanxi Province, China. Tourism Management, 63, 223-233. https://doi.org/10.1016/j.tourman.2017.04.003

Giới thiệu chung về Vĩnh Phúc [General introduction of Vinh Phuc Province] (2019, $\begin{array}{llll}\text { September 12). } & \text { Retrieved }\end{array}$ https://vinhphuc.gov.vn/ct/cms/thongtingioithieu/Lists/gioithieuchungn/View_Detail.aspx?Ite $\mathrm{mID}=1$

Kastenholz, Carneiro, Marques, \& Lima. (2012). Understanding and managing the rural tourism experience - The case of a historical village in Portugal. Tourism Management Perspectives, 4, 207-214. https://doi.org/10.1016/j.tmp.2012.08.009

Lane, B., \& Kastenholz, E. (2015). Rural tourism: The evolution of practice and research approaches - towards a new generation concept? Journal of Sustainable Tourism, 23(8-9), 1133-1156. https://doi.org/10.1080/09669582.2015.1083997 
Le, H. (2019, April 23). Vĩnh Phúc phát triển du lịch đặc trung bền vũng [Vinh Phuc Province develops featured tourism sustainably]. Retrieved from https://baomoi.com/vinh-phuc-phat-trien-du-lich-dac-trung-ben-vung/c/30456706.epi.

Mitchell, J. (2012), Value chain approaches to assessing the impact of tourism on low income households in developing coutries. Journal of Sustainable tourism, 20(3), 457-475. Doi: https://doi.org/10.1080/09669582.2012.663378

Nguyen, H. (2018, January 04). Giải bài toán nhân lực cho ngành du lịch [Solving human resource problems for tourism]. Retrieved from http://baovinhphuc.com.vn/xa-hoi/tin-tuc/45886/giai-bai-toan-nhan-luc-cho-nganh-du-lich.ht $\mathrm{ml}$.

Pham, H. M. (2009). Factors affecting travel entertainment demand for domestic tourism in Nha Trang Bay marine protected area. Journal of Science Fisheries Technology, Special number, 216-222.

Pham, M. C. (2013). Environmental pollution of Vinh Phuc craft villages: current situation and solutions. Environment Magazine, 12/2013.

Robert, W. M., Charles, R. G., \& Brent Ritchie, J. R. (1995). Tourism: principles, practices, philosophies $\left(7^{\text {th }}\right.$ ed.). New York, John Wiley and Sons.

Song, et al. (2010). Tourism economics research: A review and assessment. Annals of Tourism Research, 39(3), 1653-1682. https://doi.org/10.1016/j.annals.2012.05.023

Suzuki, N. (2006). Effective Tourism Development through Traditional Craft Promotion-Japanese Experiences. First International Congress on Tourism and Traditional Craft \& Associated Activities. Riyadh, KSA November.

Vinh Phuc Statistical Office (2011-2017). Statistical yearbook of Vinh Phuc Province. Vinh Phuc, Vinh Phuc Statistical Office.

Vo Thi, M. T. (2012). Orientation of developing traditional craft villages in Tra Vinh province to serve tourism in the integration period (Master thesis). Ho Chi Minh University of Education, Ho Chi Minh, Vietnam.

Vu, M. H., \& Ida, R. (2017). Craft villages and tourism development, a case study in Phu Quoc island of $\quad$ VietNam. 223-236. https://doi.org/10.1515/manment-2015-0090

Williams, \& Lawson. (2001). Community issues and resident opinion of tourism. Annals of Tourism Research, 28(2), 269-290. https://doi.org/10.1016/S0160-7383(00)00030-X

World Tourism Organization (2008). UNWTO Tourism Highlights, Edition 2008. https://doi.org/10.18111/9789284413560 


\section{Copyright Disclaimer}

Copyright for this article is retained by the author(s), with first publication rights granted to the journal.

This is an open-access article distributed under the terms and conditions of the Creative Commons Attribution license (http://creativecommons.org/licenses/by/4.0/). 